\title{
Determinants of Factors Affecting The Performance of Employees
}

\author{
Andi Surya ${ }^{1}$, Desmon $^{2}$, Maria Sepjiantini Alie ${ }^{3}$ \\ \{andisangsurya@umitra.ac.id ${ }^{1}$, desmon@umitra.ac.id ${ }^{2}$, maria_alie@umitra.ac.id ${ }^{3}$ \} \\ 1,2,3 Lecturer of Economic Faculty, Universitas Mitra, Indonesia
}

\begin{abstract}
The objective this study is to determine the influence of the environment, discipline, and years of service to employee performance. This study was done from April to July 2019. The location of the study was at the Office of the Regional Tax and Retribution Management Agency in Bandar Lampung City. This study used survey methods and the number of samples is 40 . The data were elaborated using multiple linear regressions. The results of study got are $\mathrm{Y}=5.498+0.797+0.453+0.108+\mathrm{e}$. The coefficient of determination $(\mathrm{R} 2)=0.780$ means that $78 \%$ of staff performance is affected by discipline, environment, and years of service. Based on the F-test, it was found that the work discipline, work environment, and year of service simultaneously had a meaningful effect on staff performance. Based on t-test got perform confusion, work discipline and year of service individually has a meaningful effect on employee performance.
\end{abstract}

Keywords : Environtment, Discipline, Working Mass, and Employee Performance

\section{Introduction}

Human resources are a strategic element on determining whether an organization is progressing or not. Planned and sustainable development of human resources is an absolute necessity of the organization. The success of achieving organizational goals is highly affected by the work of its employees. In connection with improving employee performance, many factors influence it, including in working environment, work discipline and years of service. Nitisemito (2010) stated that the working environment is everything occurred over the employees and can affect them in doing the tasks[1]. Another factor that plays a role in improving performance is work discipline. Based to Sutrisno (2010), discipline is an attitude of honor for company instruction and regulations, that exists in employees and causes a person to adapt themselves willingly to company rules and regulations[3].

Many facts occurred that allegedly related to the work environment that is less supportive, the less of employees work discipline in supporting their work, as well as the work impression of the employees. However, it needs to be further investigated through empirical study titled "The Effect of the Work Environment, Work Discipline, and Working Period on Employee Performance at Bandar Lampung Regional Agency for Tax and Retribution.

This study aims (1) to find out the effect of the work discipline, work environment, and years of service on employee performance at Bandar Lampung Regional Agency for Tax and Retribution. (2) To identify the result of the working environment on staff performance at the Regional Office of the Tax Management and Retrebusi City of Bandar Lampung City. (3) to identify the result of work discipline on employee performance in Bandar Lampung Regional Agency for Tax and Retribution, and (4) to identify the effect of the working period on employee performance at the Bandar Lampung Regional Agency for Tax and Retribution. 


\section{Literature Review}

\subsection{Employee Performance}

Mangkuprawira and Hubeis (2007) say that achievement is the result of certain planned work processes at the time and place of the staff and the organization concerned[5]. Meanwhile, based to Mangkunegara (2010) believes that employee performance is the result of quality and quantity of work achieved by an employee in carrying out their duties in accordance with the responsibilities given to them[7].

Based to Bernardin and Russell (2003), there are three indicators used to measure employee performance, they are quality of work, knowledge, and cooperation[8].

\subsection{Working environment}

The working environment is anything around the workers and influences them in doing the tasks assigned[1]. Schultz \& Schultz (2006) defines the working environment as a situation related to the characteristics of the workplace to employee habit and attitudes where it is relevant to changes of psychological things due to things had in his work or in certain circumstances that must noticed by organizations including work boredom, monotonous work and fatigue[10]. Indicators of the working environment proposed by Nitisemito (2010) are work atmosphere, relationships with colleagues, relations between subordinates and leaders, and the availability of work facilities[1].

\subsection{Work Discipline}

Handoko (2012) explained, discipline is a managerial activity for implementing organizational standards[2]. Meanwhile, based to Sutrisno (2010), discipline is an attitude for corporate instructions and regulations, which exists in employees and causes a person to adjust themselves willingly to company rules and regulations[3]. Based to Tohardi (2002) work discipline is a behavior of a person that is in agreement with existing work isntruction regulations[12].

\subsection{Years of Service}

Siagian (2015) stated that year of services is a whole lesson learned by a person from the events passed in his life journey[13]. Meanwhile, based to Nitisemito (2000), the years of service is the duration of time an staff donates his strength to a particular corporate[1]. The level to which the workforce can get splendid results in work depends on the skills, ability, and some other skills in order to carry out their work properly

\section{Conceptual Framework}

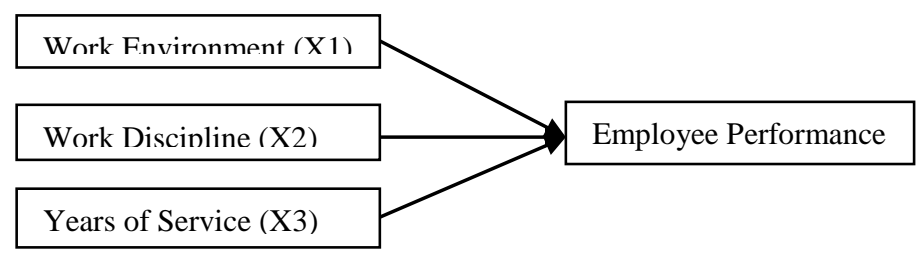

Fig. 2.1. Conceptual Framework 


\subsection{Hypothesis}

The hypothesis in the research are formulated as follows:

1. Ho: It is suspected there is no significant affect among the work discipline, work environment, and work period on the performance of the employees of Bandar Lampung Regional Tax and Retribution Management Board.

2. Ho: It is suspected that there is a significant influence between the Work Environment on Bandar Lampung Regional Tax and Retribution Management Board.

3. Ho: It is suspected that there is a significant influence between Work Discipline on Bandar Lampung Regional Tax and Retribution Management Board

4. Ho: It is suspected that there is a significant influence between the Working Period on Bandar Lampung Regional Tax and Retribution Management Board

\section{Research Methodology}

\subsection{Research design}

The design used was a survey method with a quantitative approach. In this study the variables used are the independent variable $(\mathrm{X})$ and dependent variable $(\mathrm{Y})$ and. The dependent variable is representing Employee Performance, and the independent variable used consists of 2 variables, in which $\mathrm{X} 1$ is the Work Environment, $\mathrm{X} 2$ is the Work Discipline and $\mathrm{X} 3$ is the Working Period. To study the effect of the dependent variable (Y) and the independent variable (Xi) in this research using the Multiple Regression Linear model. The general equation can be written as follows:

$$
Y=a+b 1 X 1+b 2 X 2+b 3 X 3+e
$$

To test the hypothesis of the effect of independent variables $(\mathrm{Xi})$ in common to the dependent variable $(\mathrm{Y})$ using the $\mathrm{F}$ test, while to test the hypothesis of the influence of the independent variables (partial) using the $t$ test.

\subsection{Place and time of research}

The study was done at Bandar Lampung Regional Tax and Retributioni Management Agency, which is located at Jalan Dr. Susilo Number 02 Bandar Lampung City. This study was conducted in April to July 2019.

\subsection{Population and Sample}

The population sample referred to in this study is 169 employees. The sampling technique in this study uses simple random sampling technique. The large number of samples taken if the population is homogeneous is $25 \%$ [14]. The samples in this study were 40 people.

\subsection{Definition of Operational Variables}

\subsubsection{Work Environment (X1)}

The environment of work is anything which is occurred around the workers and that effect them in doing tasks assigned[1]. The corporates should be able to reflect situations that support cooperation between the level of superiors, subordinates and those who have the same position condition in the company. The concept of the work environment in this study was measured by indicators which are work atmosphere, relationships with colleagues, relations between subordinates and leaders, and the availability of work facilities. 


\subsubsection{Work Discipline (X1)}

Work discipline is as an implementation of management to reinforce organizational guidelines. In an organization a leader requires a tool for communication with employees about the behavior of employees, and how to improve the behavior of employees for the better, and work discipline applied by the leader communication tools[7]. The concept of work discipline in this study is measured by indicators which are integrity, obeying organizational regulations, obeying working hours and time management.

\subsubsection{Working Period (X3)}

Based to Siagian (2015), stated working period is a whole lesson learned by a person from the events that are passed in his life journey[13]. Meanwhile, Nitisemito (2010) stated the length of service is the length of time an employee donates his strength to a particular company[1].

\subsubsection{Employee Performance (Y2)}

Based to Handoko (2012), the meaning of the word performance comes from the word work performance and is also called true performance or proper performance that has been succeed by an employee[2].

\section{Results And Discussion}

\subsection{Study Result}

Based on study results shows from 40 respondents who are employees of the Bandar Lampung Regional Tax and Retribution Agency, there are 13 men with a percentage of $32.50 \%$ and 17 women with a percentage of $67.50 \%$, thus showing that employees of the Bandar Lampung City Regional Tax and Retribution Agency are dominated by female employees. Based on study, the results show that the most number of employees from the number of respondents is aged between 31-40 years with a total of 20 respondents or $50.00 \%$. This shows that the employees of the Bandar Lampung Regional Tax and Retribution Management Agency are dominated by employees of productive age and can further improve the performance of their employees. Based on study, results show that the most number of BPRD employees from number of respondents is having a bachelor level of education with a total of 23 respondents or $57.50 \%$. This shows that the employees of the Bandar Lampung Regional Tax and Retribution Agency already have a very good level of education.

\subsection{Data Analysis Results}

\subsubsection{Multiple Linear Regression Test}

This study uses three independent variables which are Work Environment (X1), Work Discipline (X2) and work period (X3). While the dependent variable is employee performance (Y). To determine the effect of independent variables and dependent variables using the Multiple Liner Regression test. The results of the analysis were got the multiple linear regressions equation is not as follows:

$$
\mathrm{Y}=5.489+0.797 \mathrm{X} 1+0.108 \times 3+\mathrm{e}
$$


The coefficient values of the equation can be explained as follows:

1. A constant value of 5.489 means that when the variable work environment (X1) and work discipline (X2), and Year of Service (X3) is zero, the Employee Performance is 5.489 units.

2. Regression coefficient $\mathrm{X} 1=0.798$ states that each addition of $\mathrm{X} 1$ (Work Environment) by one unit will increase Employee Performance by 0.845 units.

3. Regression coefficient X2 $=0.797$ states that each addition of $\mathrm{X} 2$ (Work Discipline) of one unit will increase Employee Performance by 0.409 units.

4. Regression coefficient X3 $=0.108$ states that each addition of $\mathrm{X} 3$ (Work Discipline) of one unit will increase Employee Performance by 0.108 units.

\subsubsection{Determination Coefficient Test (R2)}

The coefficient of determination (R2) aims to quantify how far the ability of model to describe the variety of the dependent variable. The score of the coefficient of definition is 0 $<\mathrm{R} 2<1$. The coefficient of definition close to one means that the independent variable presents some information requires predicting the dependent variable. Adjusted R Square Determination coefficient is 0.762 , which means that the independent variables consisting of Work Environment, Work Discipline, and Year of Service have an effect of $76.2 \%$ while the rest $23.8 \%$ is influenced by other factors.

\subsubsection{F-test}

The F-test is carried out with level of $\alpha=5 \%$ and a degree of freedom of numerator of $\mathrm{k}$ (number of independent variables) minus one or $(\mathrm{k}-1)=3-1=2$ and the degree of denominator freedom of $n-k=40-3=37$. The result got values Fcount $=42.553>$ Ftable $=$ 2.86 with $\alpha=0.05$, then H1 is accepted and Ho is rejected, so it can be concluded that the independent variables consisting of Work Environment (X1), Work Discipline (X2), and Year of Service (X3) have a significant simultaneous effect on the dependent variable Employee Performance $(\mathrm{Y})$.

\subsubsection{T-test}

The results shows the work environment variable $(\mathrm{X} 1)$ got value $\mathrm{t}$ Count $=5.468>\mathrm{t}$ table $=1.684$ then $\mathrm{H} 1$ is accepted and Ho is rejected at the level of $\alpha=0.05$, it can be concluded that the Work Environment variable (X1) has significant influence on Employee Performance (Y). Whereas for work discipline variables, the value of tcount $=3.456>$ ttable $=1.684$, which means that $\mathrm{H} 1$ is accepted and Ho is rejected with a level of confidence $\alpha=0.05$, so it can be concluded that the Work Discipline variable (X1) partially influences the significance of Employee Performance (Y). In the year of service variable, the value of $t_{\text {count }}=2.143>t_{\text {table }}=$ 1.684, which means that $\mathrm{H} 1$ is accepted and Ho is rejected with a level of confidence $\alpha=0.05$, so it can be concluded that the variable of the years of service (X1) partially has a significant influence on employee performance (Y)

\section{Discussion}

The results shows the work environment variable $(\mathrm{X} 1)$ got value $\mathrm{t}$ Count $=5.468>\mathrm{t}$ table $=1.684$ then $\mathrm{H} 1$ is accepted and Ho is rejected at the level of $\alpha=0.05$, so it can be concluded 
that the Work Environment variable (X1) has partial significant influence on Employee Performance (Y).

While for the work discipline variable, the value of tcount $=3.456>$ ttable $=1.684$ means that $\mathrm{H} 1$ is accepted and Ho is rejected with a level of $\alpha=0.05$, so it can be concluded that the Work Discipline variable (X2) partially influences the significant effect on Employee Performance (Y). Based to Tohardi (2002) work discipline is a person's behavior that is in accordance with existing work procedure regulations[12].

In the Year of service variable, the value of $t$ count $=2.143>$ ttable $=1.684$, which means that $\mathrm{H} 1$ is accepted and Ho is rejected with a level of $\alpha=0.05$, so it can be concluded that the variable of the years of service (X1) partially has a significant effect on employee performance (Y). Based to Siagian (2015), Year of Service is a whole lesson learned by a person from the events that are passed in his life journey. How far the workers can get satisfactory results in work based on the skills, ability, and some significant skills in order to carry out their work properly. Longer year of service has a positive impact on income levels. Longer work experience has an impact on welfare. The year of service in this study is counted as years.

\section{Conclusions}

\subsection{Conclusion}

1. Work environment variety, work discipline and years of service together have significant effect on the achievement of employees of Bandar Lampung City Tax and Retribution Management Office.

2. The work environment variable partially influences the performance of the employee of Bandar Lampung City Tax and Retribution Management Office.

3. The work discipline variable partially influences the performance of the employee of Bandar Lampung City Tax and Retribution Management Office.

4. The year of service variable partially influences the employee performance of Bandar Lampung City Tax and Retribution Management Office.

\subsection{Suggestion}

In order to improve employee performance, Bandar Lampung City Tax and Retribution Management Agency (BPRD) should be able to create a conducive work environment both in atmosphere and facilities so that employees can work well. In addition to the work environment, employee discipline must be improved continuously by giving appreciation and punishment to the staff that broke the rules. In consequence, environmental factors, discipline, and years of service need to be taken into consideration in an effort to fix employee performance.

\section{References}

[1] A. S. Nitisemito, Manajemen Personalia. Jakarta: Ghalia Indonesia, 2010.

[2] T. H. Handoko, Manajemen Personalia \& Sumber Daya Manusia, 2nd ed. Yogyakarta: BPFE Yogyakarta. Universitas Setia Budi Surakarta, 2012.

[3] E. Sutrisno, Manajemen Sumber Daya Manusia, 1st ed. Jakarta: Kencana, 2010.

[4] B. P. P. dan D. K. B. Lampung, "Buku Laporan Tahunan,” Bandar Lampung, 2018. 
[5] S. Mangkuprawira and A. V. Hubeis, Manajemen Mutu Sumber Daya Manusia. Bogor: Ghalia Indonesia, 2007.

[6] V. Rivai, Manajemen SDM untuk Perusahaan dari Teori ke Praktik. Jakarta: PT Raja Grafindo Persada, 2004.

[7] A. P. Mengkunegara, Manajemen Sumber Daya Perusahaan. Bandung: Remaja Rosdakarya, 2011.

[8] H. J. Bernardin and J. E. Russel, Human Resource Management (An Experimental Approach International Edition). Singapore: Mc. Graw-Hill Inc, 2003.

[9] H. Suprihatiningrum and T. Bodroastuti, "Faktor-Faktor Yang Mempengaruhi Prestasi Kerja (Studi Pada Karyawan Kantor Kementrian Agama Provinsi Jawa Tengah), J. Kaji. Akunt. dan Bisnis, vol. 1, no. 1, pp. 1-23, 2012.

[10] G. S. Schultz et al., "Wound bed preparation: a systematic approach to wound management," Wound repair Regen., vol. 11, pp. S1-S28, 2003.

[11] B. W. Soetjipto and A. Usmara, Paradigma Baru Manajemen Sumber Daya Manusia. Amara Books, 2004.

[12] A. Tohardi, Pemahaman Praktis Manajemen Sumber DayaManusia. Bandung: Penerbit Mandar Maju, 2002.

[13] S. P. Siagian, Manajemen Sumber Daya Manusia, Cetakan 23. Jakarta: Bumi Aksara, 2015.

[14] Sugiyono, Metode Penelitian Kuantitatif, Kualitatif dan $R \&$ D. Bandung: Alfabeta, 2015.

[15] M. S. P. Hasibuan, “Organisasi dan Manajemen.” Rajawali Press, Jakarta, 2004. 